\title{
Application of aerial photographs for the assessment of anthropogenic denudation impact on soil cover of the Brodnica Landscape Park plateau areas
}

\author{
Marcin Świtoniak, Renata Bednarek, Maciej Markiewicz, Bartosz Paluszewski \\ Faculty of Earth Sciences, Nicolaus Copernicus University \\ Lwowska 1, 87-100 Toruń, Poland \\ e-mail: swit@umk.pl
}

\begin{abstract}
The aim of the study was to assess suitability of colour aerial photographs for mapping of soil cover transformed due to effect of anthropogenic denudation. The investigation was carried out in south-western part of the Brodnica Landscape Park, within the boundaries of rolling and hilly moraine plateau, used for agricultural purposes. The soil cover of that area is exposed to intensive influence of slope processes triggered by human agricultural activity. The anthropogenic denudation leads to truncation of soil profiles of top convex sections of slopes and hills' summits. Soil material moved down the slopes is accumulated in the form of diluvium in hollows and lower sections of slopes. Two study sites were selected - Sumówko and Zbiczno. Within the boundaries of both study sites, detailed soil mapping took place consisting in preparation of irregular boreholes projection. Next, four sites were selected for soil pits, representing broad spectrum of transformations related to anthropogenic denudation. Based on obtained results and colour diversity of surface horizons, the spatial range of individual soil types was specified. It also enabled determination of anthropogenic denudation impact on formation of the soil cover. Totally eroded soils, classified as pelosols, located on hills' summits, are characterized by very bright colours of surface horizons, resulting from content of calcium carbonate in glacial tills. The range of soil lessivés, prevailing within the slopes boundaries, where the erosion resulted in exposure of argic horizons rich in iron compounds and clay fraction, coincided with occurrence of brown colours. Bright grey surface horizons are characteristic of deluvial soils. This colour arises from sandy texture of deluvial material (low content of iron) in combination with humus nature. The soils located in relatively vast field depressions were covered with small thickness of diluvium, which was reflected in dark grey colours of surface horizons. These horizons are relatively rich in soil humus. Significant amounts of humus are related with mix of deluvial material with material formed in humus horizons, originally occurring on surfaces of soils rich in organic matter - black earths and organic soils.
\end{abstract}

Key words: accelerated soil erosion, soil redistribution, eroded soils, deluvial soils

\section{Introduction}

Increasing intensification of cultivations and agricultural engineering heighten the negative transformations of the environment, particularly land relief and soil cover. Among the processes triggering those transformations is anthropogenic denudation, which results in formation of anthropogenic slope terrain and in degradation of soil cover. The anthropogenic denudation means joint effects on the slope of various processes triggered and accelerated by human agricultural activity. It is therefore a set of slope processes, heightened by agronomical treatments (Sinkiewicz 1998).
The agricultural management leads to acceleration of natural processes (linear rainfall-runoff, entrainment, surface mass movements, scouring, chemical denudation) and resultant formation of specific slope terrain: flutes, erosion grooves, cones and slope covers, dells, gullies. The agronomical treatments also produce agronomical denudation, i.e. soil relocation by means of agricultural machines and tools.

Impact of anthropogenic denudation on formation of soil catenas Polish Lowlands was already described in the agricultural areas of Chełmno Plateau (Szrejder 1998), Masurian Lake District (Piaścik et al. 2001), Gniezno 
Lake District (Stasik \& Szafrański 2005), and Sępopolska Lowlands (Orzechowski 2008). Relocation of soil material from upper sections of slopes and accumulation at their bases and in field depressions lead to modification of existing soil units or origination of new ones. The soils of upheavals undergo truncation, while semi- and hydrogenic soils are buried with gradually increasing deluvial covers (Uggla \& Mirowski 1960; Uggla et al. 1968; Bieniek 1997; Koćmit 1998; Szrejder 2000; Orzechowski et al. 2001; Piaścik \& Sowiński 2002).

For field studies of anthropogenic denudation, conventional methods of soil science mapping are often insufficient due to high lithology and soil versatility as well as rapidly erased minor erosion and denudation formations through agronomical treatments. Interpretation of aerial photographs proved to be as good method, enabling recognition of anthropogenic slope formations and their monitoring over time. It allows for recognition and mapping of many formations caused by anthropogenic denudation; outline routes of the material relocations on the slope; provide much information on spatial arrangement of washing zones (Sinkiewicz 1977). A change of particle size distribution and properties of soils transformed due to anthropogenic denudation results in alteration of their spectral properties, thus to modification of their picture on an aerial photograph. A decrease of humus amount on a slope under erosion results in brighter soils on photographs. In case of eroded slopes built from clay soils, the brightest tones feature the most intensively eroded fragments of inclined surface, which results from shallower humus horizon and lower content of humus in the soil profile. Increased content of humus in lower part of the slope and increase of water content in the profile produces increased optical density of loamy, deluvial soils zones' picture. The effect of dispersed rainfall-runoff is the formation of bright spots on minor elevations and darker ones in local hollows within the boundaries of the slope (Gacki \& Gołębiewski 1977). Interpretation of aerial photographs also facilitates variability capture of factors affecting the denudation, such as land relief or type of land management. The aerial photographs are applicable in investigations of denudation processes and forms, not only in areas of large denivelations, but also in the areas of weakly diversified relief (Sinkiewicz 1977). A correct interpretation of photographs allows for recognition and assessment of soil erosion intensity within given area and is very useful for interpolations of field studies. The aerial photographs acquire special significance during investigations, preparing initial assessments of soil covers when completing review mapping (Kęsik 1969).

The first research into soil cover using aerial photographs, also with regard to deterioration of soil surface, was carried out in Poland in early 1960s. When studying phenomena of soil denudation, the researchers focused on areas of large denivelations. Most of studies concern the area of mountains and uplands of South Poland. Baraniecki (1967) attempted to specify directions of surface washings in areas featuring weak inclination, excluding the areas of distinctive valley system in the vicinity of town Racławice in front of Sudeten Mountains. Based on the example of northern edge of Chodel Basin, Kęsik (1969) undertook issues of soil erosion. The VII Polish Photointerpretation Conference in Torun (1975), involved presentations of subsequent aspects of aerial photographs suitability for investigations of soil erosion. All above listed studies were based on black-and-white (monochromatic) photographs. Also, there were attempts of completing soil maps based on aerial photographs as well as assessing the extent of anthropogenic soil transformations in the areas used for agricultural purposes (Sinkiewicz 1977). Not many authors have tried to apply aerial photographs for determination of denudation transformations of soil covers in young glacial plateau areas. Gacki and Gołębiewski (1977) applied remote sensing techniques for investigations of soil erosion within the area of Łączyno Plateau. Sinkiewicz (1977, 1990, 1998) applied interpretation of aerial photographs when investigating anthropogenic denudation in the area of Cuiavia and Chełmno Plateau.

So far completed studies of the Brodnica Landscape Park have proved significant impact of anthropogenic denudation on soil properties and soil cover structure (Świtoniak 2011). This is especially the case for plateau areas intensively used for agricultural purposes. The aim of the study was to assess suitability of colour aerial photographs for mapping of soil cover transformed due to effect of anthropogenic denudation in young glacial morainic plateau areas.

\section{Study area and methods}

The field works were carried out in south-western part of the Brodnica Landscape Park (Fig. 1). Two study sites were selected. Site one is located near Sumowo (1); site two is close to Zbiczno (2).

Surface areas of the study sites are 13.5 and 12.7 ha respectively. Both study areas are located within the boundaries of rolling and hilly moraine plateau featuring considerable land denivelation (Fig. 2). The outline of relief of the area discussed was formed during the recession of inland ice and by meltwaters of the last glaciation of late vistulian, in the Pomeranian phase ca. 17-16 ka BP (Niewiarowski \& Wysota 1986). Boulder clays, sanded in the sub-surface layer are prevailing surface formations. According to Niewiarowski (1973), this sand formation may be an effect of ablation formations deposited on the surface of boulder clay, operation of late post-glacial periglacial processes or transformations of rock substrate due to soil formation processes. In the western part of Zbiczno surface, some minor areas of sandy glaciofluvial deposits featuring high thick- 


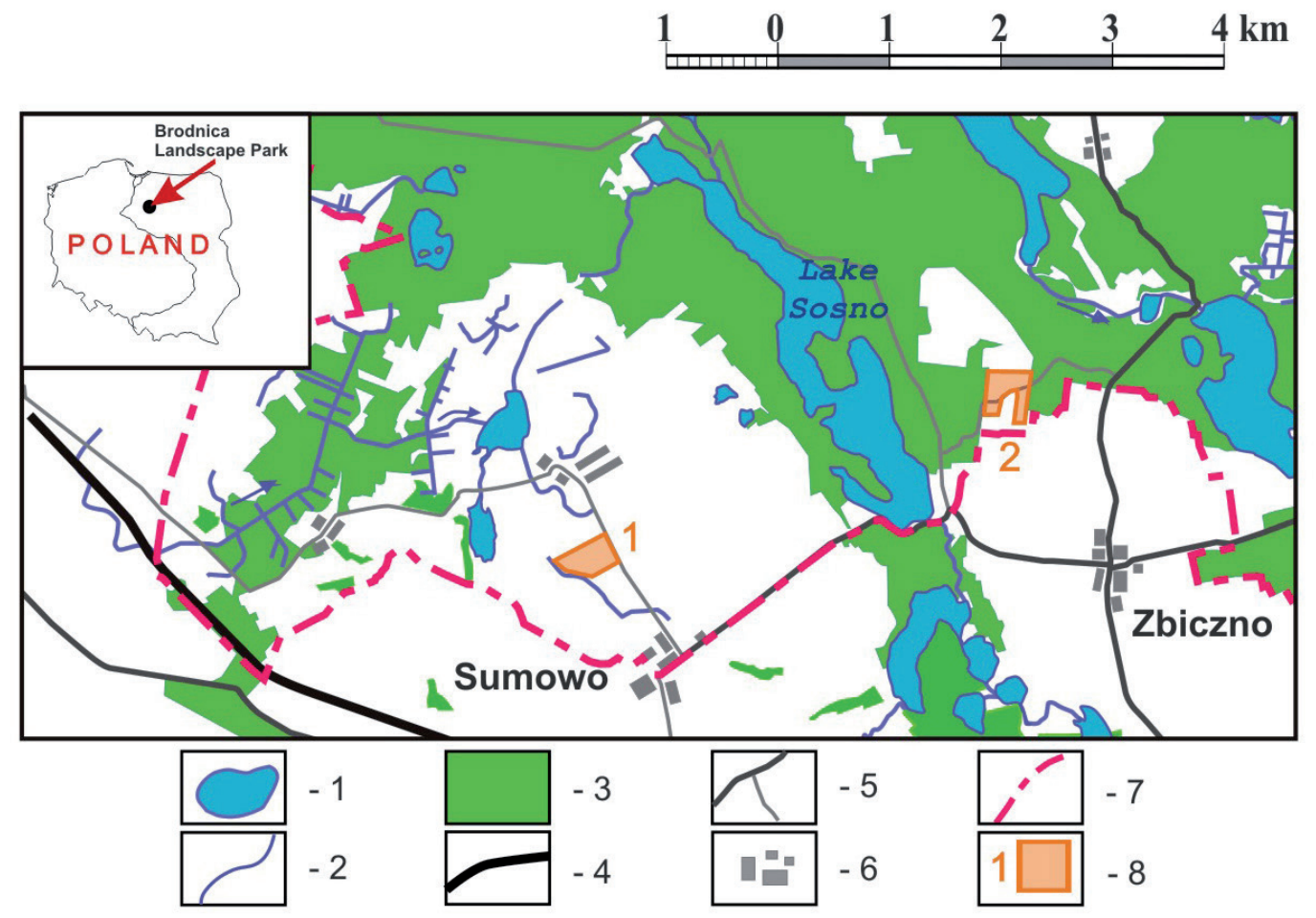

Figure 1. Localization of study area

1 - lake, 2 - river, 3 - forest, 4 - railway, 5 - roads, 6 - buildings, 7 - boundary of BLP, 8 - study site

ness were noted, related to the contact zone of moraine plateau with west Brodnica sandur. Due to agricultural use of this area (plough fields), the colours of soil surface horizons were well visible on the aerial photographs (no plant cover).

Within the boundaries of both study sites, detailed soil mapping took place consisting in preparation of irregular augerholes projection. The augerholes were made in characteristic points of mezorelief and in transects led by individual forms of relief. Five sites were selected for soil pits, representing catenal arrangement, specific for the area under investigation. The field work involved description of profiles' morphology, initial determination of soils' classification (Polish Soil Classification 2011) and creation of photographic documentation. Samples for laboratory tests were taken from all horizons. Coordinates of pits and augerholes were estimated by means of receiver Garmin GPSMAP 60CSX. The points of augerholes and soil pits were estimated with measurement accuracy of $3 \mathrm{~m}$. For estimation of spatial ranges of soils featuring specific colours of surface horizons these places were applied into orthophotomap fragments (scale 1:26 000, pixel resolution 0.5 $\mathrm{m})$. The orthophotomap uses analogue aerial photographs taken during a flight in September 2009 in spectrum visible in natural colours.
Standard soil analyses were performed in the samples of soil material: colours of dry and wet soil material using Munsell Soil Color Charts (2000); particle size distribution using Bouyoucos areometric method in the Casagrande and Prószyński modification with sand fraction separation by sieve method; volume density in samples of undisturbed structure taken into metal cylinders with a capacity of 100 $\mathrm{cm}^{3}$; actual moisture, expressed as volume percentage; organic carbon content using Tiurin method; total nitrogen content by Kjeldahl method; $\mathrm{pH}$ using potentiometric method in $\mathrm{H}_{2} \mathrm{O}$ and in solution $\mathrm{KCl}$ with concentration of $1 \mathrm{~mol} \cdot \mathrm{dm}^{-3}$; the contents of the carbonates using Scheibler method. The solid particle density was calculated based on the formula proposed by Marcinek and Spychalski (1987).

\section{Results and discussion}

Both test areas feature spotty texture of soils' picture on the aerial photographs. This picture reflects "irregularly spotty" type of soil cover structure of rolling ground morainic plateaus. Spatial variability of surface horizons' colours is strictly related to relief of both study areas (Fig. 2). Within hills' summits prevailing soil are those of bright brown or brown tones of surface horizons. Bright brown colours 
1) Sumowo
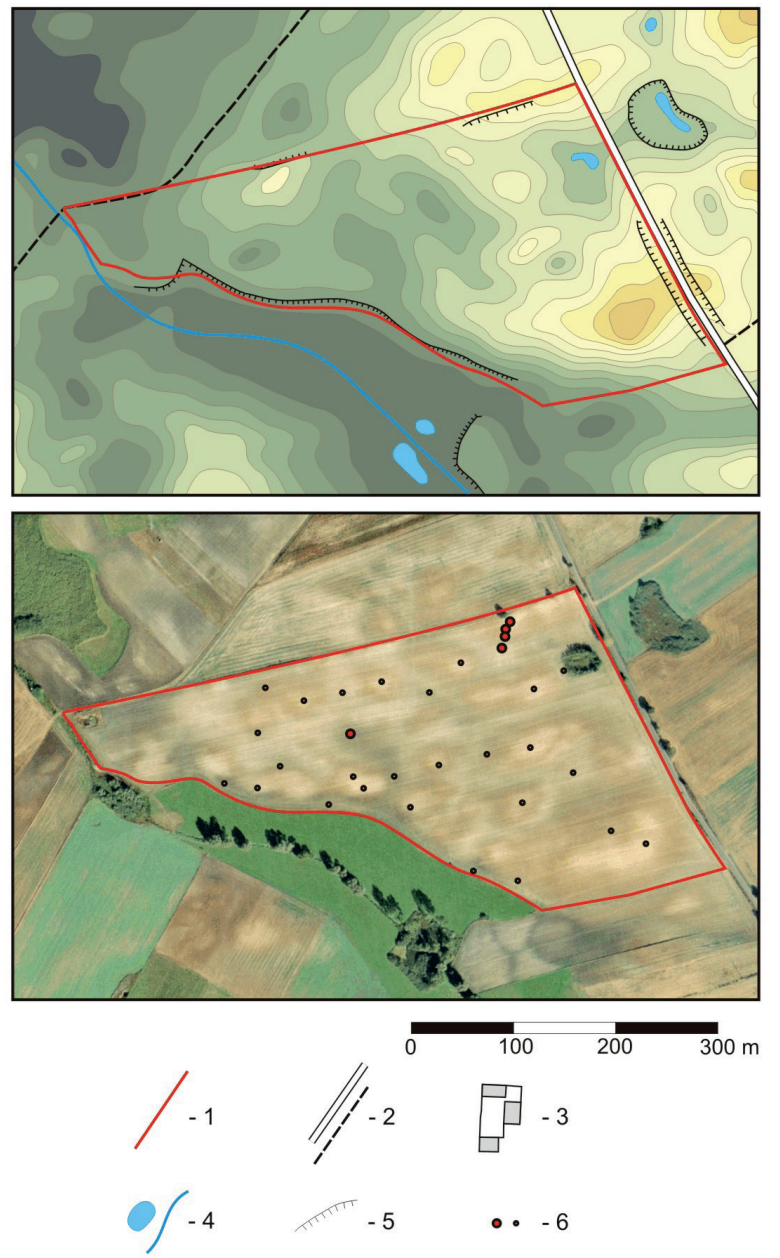

2) Zbiczno

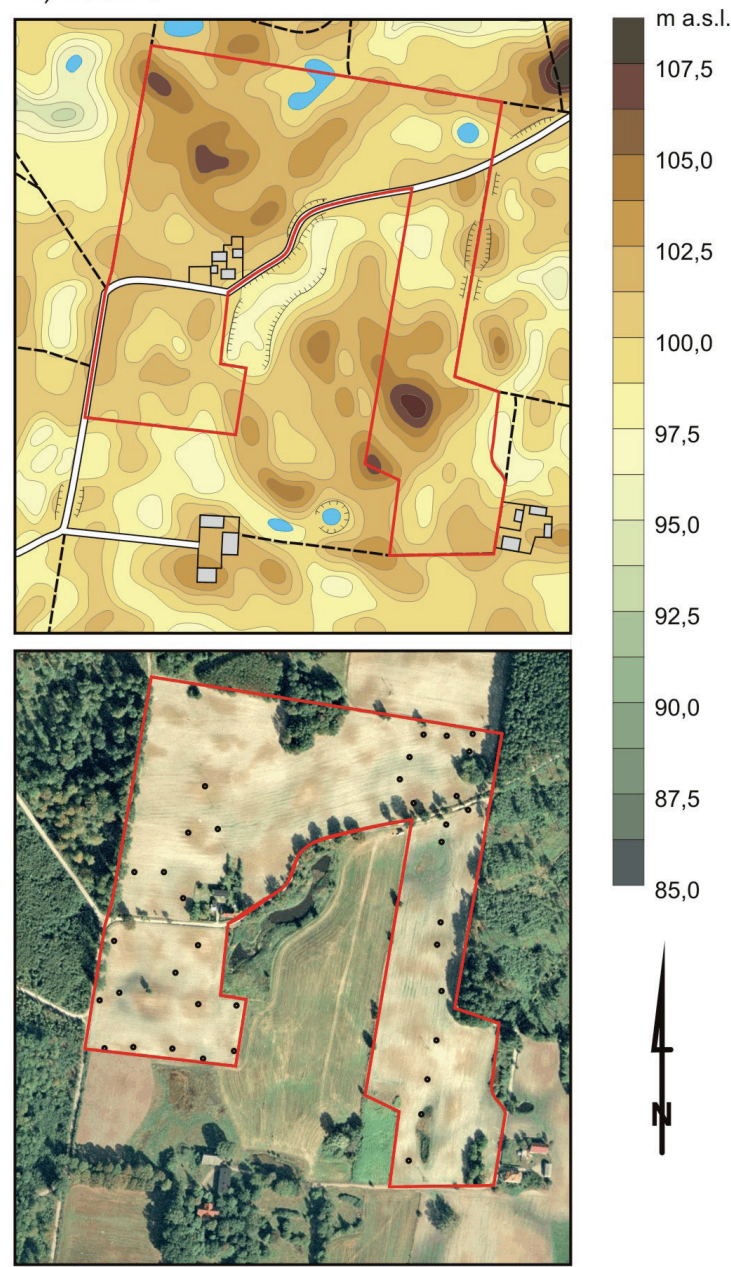

Figure 2. Topography and orthophotomaps of study sites

1 - boundary of study site, 2 - roads, 3 - buildings, 4 - lakes and rivers, 5 - scarps, 6 - soil pits and augerholes

are specific for relatively vast convex forms of Sumówko surface, while slight in terms of surface area summits at Zbiczno site are characterized by brown colour. Top, convex sections of slopes, located in the degradation zone have brown colour (similar to the colour summits' surface at Zbiczno site). Light grey colours coincide with the area of the middle and upper sections of slopes and also field holes that are slight in terms of surface area. Soils developed in the vast, often flat-bottomed, land depressions have dark grey colour surface horizons. An initial review of the aerial photographs confirms that the soils of studied area form regularly repeated catenal systems, dependent mainly on the land relief and in particular on relative height, inclination, water relations and erosion. The survey enabled implementation of soil catena concept model, representative for the studies area (Fig. 3). Development of the catena model primarily used soil morphology found in soil pits soil (Fig. 4) and augerholes as well as results of the laboratory analyses.

The summits of vast hills host pedons originated by total erosion of original soil profile, classified as weakly developed eroded loamy soil (pelosols). These soils are entirely built of glacial clays subtly transformed by pedogenesis processes (Fig. 4 - profile 1). The texture in the entire soil profile is typical of bottom glacial sediments; these are mainly loams (Tab. 1). Solum of the discussed soils is limited to weekly distinguished humus plowing horizon [ACkp or ACp] coloured 10YR 6/2; 10YR 4/3 (colour in dry; wet) close to the colour of the parent material and low organic matter content (Tab. 2). Directly below the plowing horizons, there are parent materials [Ck or $\mathrm{C}]$. Total erosion of original soil horizons is evidenced by presence, in most of pedons of these soils, of significant quantity of calcium carbonates even at the surface of land. Some 


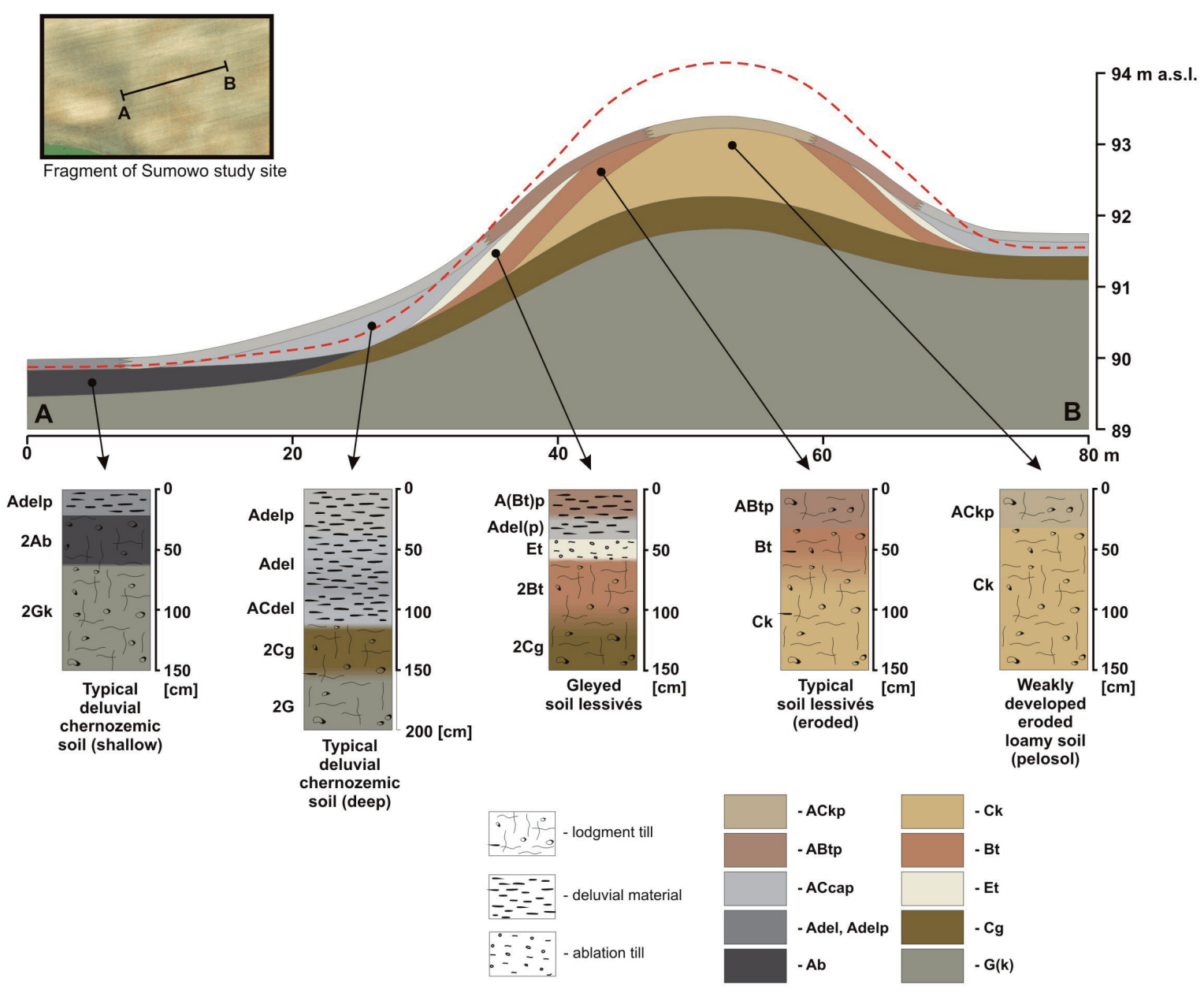

Figure 3. Cross section through soil catena of Sumowo study site

carbonates produce formations of secondary accumulation - concretions, root pseudomorphes, coatings on the soil aggregates. Forms of this type could have originated only in the parent material of originally occurring fully developed soils - probably soil lessivés. In rare cases, mainly within the Zbiczno site, pelosols are made of acidic bottom glacial tills with no content of carbonates.

In the top, convex sections of slopes or at the summits of small in terms of surface area hills dominate soil lessivés ABtp-Bt-Ck (Fig. 4 - profile 2). Lack of eluvial horizons resulted from partial truncation of these soils. Morphologically, they are very similar to brown soils. Earlier studies carried out within Brodnica Lake District (Świtoniak 2010) confirmed illuvial nature of enrichment horizons. These horizons arose therefore as a result of lessivage process effect, not the browning process. Occurrence of soil lessivés morphologically eroded resembling brown soils were also described by Józefaciuk et al. (1996) in research on water erosion in hill areas; Sinkiewicz (1998) in the study of anthropogenic denudation in the central part of North Poland; Phillips et al. (1999) in the study of erosion intensiveness in North Carolina, USA; and Marcinek and Komisarek (2004) when assessing anthropogenic transformations of Poznań Lake District. Presence on Chełmno Plateau of eroded soil lessivés and strongly eroded weakly developed loamy soil was also discussed by Bednarek and Szrejder (2004). Plowing horizons [ABtp] of these eroded soil lessivés contain mainly material forming original illuvial horizons argic and feature small amounts of organic matter (Tab. 2). They also contain an admixture of carbonate material derived from eroded pelosols located higher, which affects their alkaline reaction.

The soil lessivés with preserved eluvial horizons Et mainly occur in the middle and lower sections of slopes (Fig. 4 - profile 3 ). These soils also very often undergo a gleying process associated with both, stagnation of rainwater (pseudogley soil lessivés) at horizons Bt, and capillary rise of ground waters (gleyed soil lessivés). Surface 

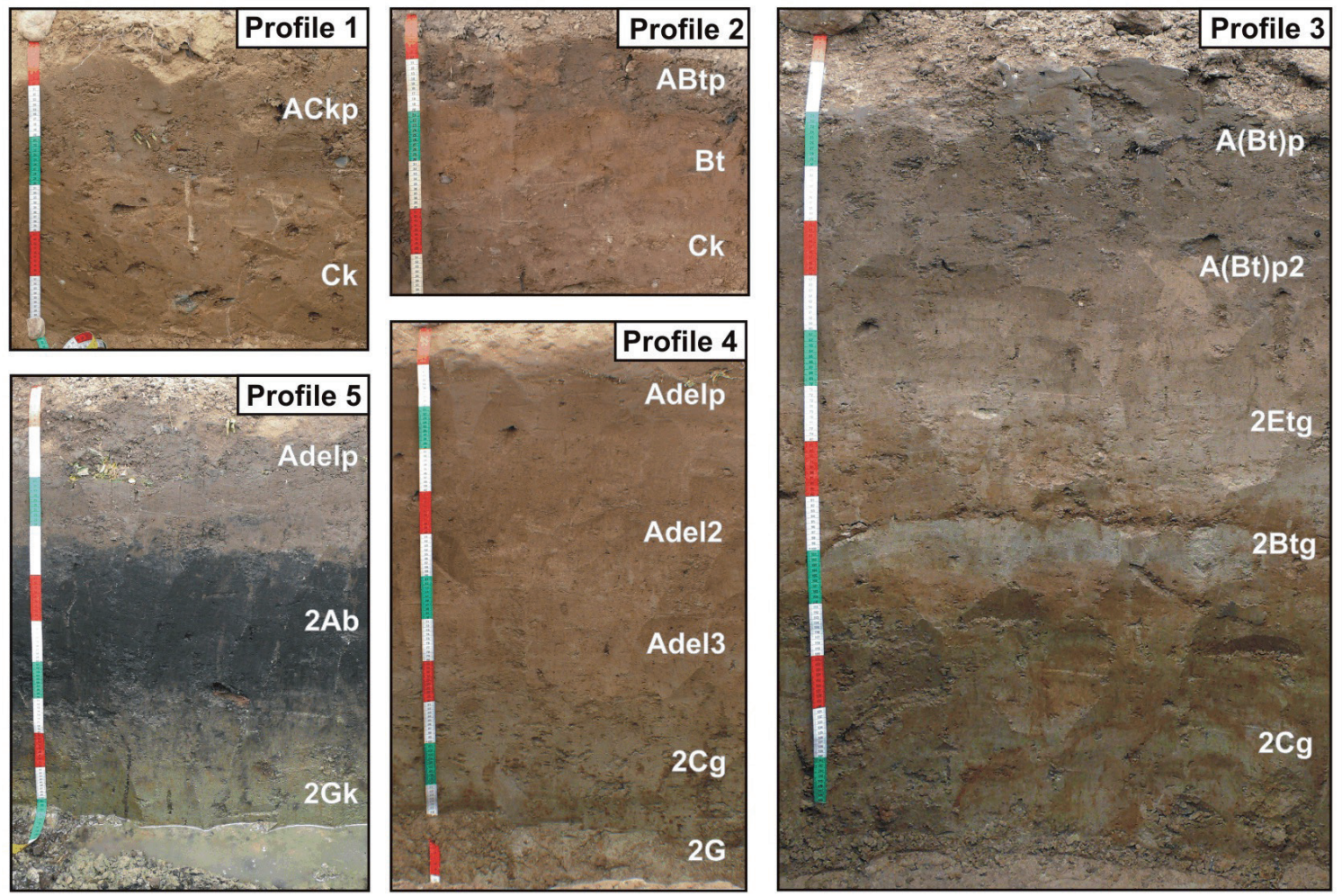

Figure 4. Morphology of investigated soils

horizons of these soils feature significant genetic differentiation. Some surface horizons of soil lessivés discussed contain significant quantities of material originated in horizons Bt eroded in upper parts of slopes. A confirmation of this fact lies both in brown colour of this material (10YR $5 / 3 ; 10 Y R 3 / 2$ ), and in greater content of clay fraction compared to eluvial horizons (Tab. 1). A phenomenon of genetic horizons' inversion consisting in the provision of material produced by erosion of soil endopedons in the upper sections of the slopes to surface horizons of soils located lower was earlier described by Alba et al. (2004) in soils of rolling lands of Minnesota, United States. In turn, the humus horizons of gleyed soil lessivés located in lower parts of slopes, are light grey (10YR 6/2; 10YR $4 / 2$ ) and have slight content of clay fraction. They contain humus and eluvial material derived from weakly eroded soil lessivés.

Immediately at the bases of slopes and in slight field hollows, there are deluvial soils of variable thickness of deluvium, sometimes exceeding $100 \mathrm{~cm}$. Those soils may be divided into shallow deluvial soils (deluvium of thickess $30-50 \mathrm{~cm})$ and deep ones $(>50 \mathrm{~cm})$. In terms of properties, the deluvial material resembles plough horizons of soil lessivés located in lower parts of slopes. It features light grey colour (10YR 6/2; 10YR 4/2), organic carbon content below 1\% (Tab. 2), and texture of loams (Tab. 1). Under the deluvial horizons, as a rule, there are no buried humus horizons of gleyed soil, originally occupying the land surface (Fig. 4 - profile 4). Due to agronomical treatments, they have been totally mixed with gradually accumulated deluvium. Lack of those horizons proves their originally slight thickness, which did not exceed the plough depth (ca. $30 \mathrm{~cm}$ ).

Vast field depressions host shallow deluvial soils (deluvium thickness from 30 to $50 \mathrm{~cm}$ ) covering soils rich in organic matter - black earths (Fig. 4 - profile 5) and various types of organic soils. The surface deluvial horizons [Adelp] contain both, material brought from upper parts of slopes, and ploughed in humus or organic material from lower horizons. Moisture and humus content in plough horizons of these soils are the highest in the entire catenal system (Tab. 2). Both mentioned factors affect dark grey colour (10YR 4/1; 10YR 2/3) of horizons Adelp.

The analysis of aerial photographs enabled relatively accurate outline of soil contours and individual components of discussed catenal system (Fig. 5).

Range of occurrence of pelosols rich in carbonates [ACkp-Ck] is easy to estimate based on aerial photo- 
Table 1. Selected physical properties and texture of the investigated soils

\begin{tabular}{|c|c|c|c|c|c|c|c|c|c|}
\hline \multirow{3}{*}{ Horizon } & \multirow{3}{*}{$\begin{array}{l}\text { Depth } \\
{[\mathrm{cm}]}\end{array}$} & \multirow{3}{*}{$\begin{array}{c}\text { Bulk } \\
\text { density } \\
{\left[\mathrm{g} \cdot \mathrm{cm}^{-3}\right]}\end{array}$} & \multirow{3}{*}{$\begin{array}{l}\text { Solid } \\
\text { particle } \\
\text { density } \\
{\left[\mathrm{g} \cdot \mathrm{cm}^{-3}\right]}\end{array}$} & \multirow{3}{*}{$\begin{array}{c}\text { Porosity } \\
{[\%]}\end{array}$} & \multirow{3}{*}{$\begin{array}{c}\text { Moisture } \\
{[\% \text { vol. }]} \\
(28.09 .2010)\end{array}$} & \multicolumn{4}{|c|}{ Texture according to PTG'08 } \\
\hline & & & & & & \multicolumn{3}{|c|}{ Particle size distribution, [\%] } & \multirow{2}{*}{$\frac{n}{\frac{0}{0}}$} \\
\hline & & & & & & 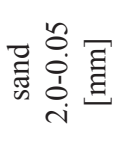 & 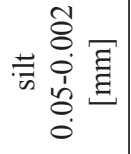 & 离 & \\
\hline \multicolumn{10}{|c|}{ Profile 1 - weakly developed eroded loamy soil } \\
\hline ACkp & $0-27$ & 1.66 & 2.64 & 34.6 & 23.6 & 67 & 20 & 13 & SL \\
\hline $\mathrm{Ck}$ & $27-60$ & 1.86 & 2.65 & 33.7 & 20.5 & 71 & 21 & 12 & SL \\
\hline \multicolumn{10}{|c|}{ Profile 2 - typical soil lessivés (eroded) } \\
\hline ABtp & $0-20$ & 1.74 & 2.64 & 34.1 & 22.8 & 56 & 23 & 21 & $\mathrm{~L}$ \\
\hline $\mathrm{Bt}$ & $20-40$ & 1.79 & 2.65 & 32.4 & 26.4 & 55 & 25 & 20 & $\mathrm{~L}$ \\
\hline $\mathrm{Ck}$ & $40-70$ & 1.71 & 2.65 & 35.5 & 23.1 & 67 & 20 & 13 & SL \\
\hline \multicolumn{10}{|c|}{ Profile 3 - gleyed soil lessivés } \\
\hline $\mathrm{A}(\mathrm{Bt}) \mathrm{p}$ & $0-30$ & 1.72 & 2.62 & 35.6 & 27.3 & 67 & 18 & 15 & SL \\
\hline $\mathrm{A}(\mathrm{Bt}) \mathrm{p} 2$ & $30-55$ & 1.68 & 2.64 & 36.4 & 21.8 & 69 & 19 & 12 & SL \\
\hline 2Etg & $55-75 / 100$ & 1.60 & 2.65 & 39.7 & 20.3 & 73 & 20 & 7 & SL \\
\hline 2Btg & $75 / 100-110$ & 1.70 & 2.64 & 37.3 & 27.7 & 58 & 23 & 19 & $\mathrm{~L}$ \\
\hline $2 \mathrm{Cg}$ & $110-160$ & 1.69 & 2.65 & 35.2 & 33.3 & 60 & 23 & 17 & $\mathrm{~L}$ \\
\hline \multicolumn{10}{|c|}{ Profile 4 - typical deluvial chernozemic soil } \\
\hline Adelp & $0-30$ & 1.74 & 2.62 & 32.9 & 24.5 & 63 & 27 & 10 & $\mathrm{~L}$ \\
\hline Adel2 & $30-55$ & 1.59 & 2.64 & 40.7 & 22.6 & 60 & 30 & 10 & $\mathrm{~L}$ \\
\hline Adel3 & $55-80$ & 1.56 & 2.64 & 41.6 & 21.5 & 66 & 26 & 8 & SL \\
\hline $2 \mathrm{Cg}$ & $80-120$ & 1.44 & 2.65 & 46.0 & 24.3 & 71 & 19 & 10 & SL \\
\hline $2 \mathrm{G}$ & $120-150$ & 1.53 & 2.65 & 41.3 & 31.2 & 64 & 21 & 15 & SL \\
\hline \multicolumn{10}{|c|}{ Profile 5 - typical deluvial chernozemic soil } \\
\hline Adelp & $0-32$ & 1.61 & 2.61 & 41.8 & 36.2 & 54 & 34 & 12 & $\mathrm{~L}$ \\
\hline $2 \mathrm{Ab}$ & $32-75$ & 1.59 & 2.60 & 39.9 & 33.7 & 61 & 23 & 16 & $\mathrm{~L}$ \\
\hline $2 \mathrm{Gk}$ & $75-110$ & 1.74 & 2.65 & 35.3 & 36.2 & 63 & 23 & 14 & $\mathrm{~L}$ \\
\hline
\end{tabular}

graphs. These soils feature light brown colour of surface horizons, sometimes almost white, which is related to drying of these soils (rapid outflow of rainwater) and presence of carbonates that lighten brown colour of moraine tills. Occurrence of pelosols in the area under investigation is associated with an intensive degradation of the soil cover. Therefore, contours of these soils are oval and coincide with the summit zone of vast plateau hills.
Contours of eroded soil lessivés [ABtp-Bt-Ck] were joined into association with non-truncated soil lessivés covered with the material from eroded (in higher field locations) horizons Bt [ABtp-Et-Bt-Ck]. This association also includes rarely occurring pelosols developed from acidic, carbonate-free lodgement tills [ACp-Cp]. In each case, the soil surface horizons are brown. The major pigments involved are oxidized iron compounds. Allocation of indi- 
Table 2. Selected chemical and physicochemical properties of the investigated soils

\begin{tabular}{|c|c|c|c|c|c|c|c|}
\hline \multirow{2}{*}{ Horizon } & \multirow{2}{*}{$\begin{array}{l}\text { Depth } \\
{[\mathrm{cm}]}\end{array}$} & \multicolumn{2}{|c|}{$\mathrm{pH}$} & \multirow{2}{*}{$\begin{array}{c}\mathrm{CaCO}_{3} \\
{[\%]}\end{array}$} & \multirow{2}{*}{$\begin{array}{c}\mathrm{OC} \\
{[\%]}\end{array}$} & \multirow{2}{*}{$\begin{array}{c}\mathrm{Nt} \\
{[\%]}\end{array}$} & \multirow{2}{*}{$\mathrm{C} / \mathrm{N}$} \\
\hline & & $\mathrm{H}_{2} \mathrm{O}$ & $\mathrm{KCl}$ & & & & \\
\hline \multicolumn{8}{|c|}{ Profile 1 - weakly developed eroded loamy soil } \\
\hline ACkp & $0-27$ & 8.4 & 7.8 & 10.9 & 0.35 & 0.031 & 11 \\
\hline $\mathrm{Ck}$ & $27-60$ & 8.8 & 8.0 & 11.4 & - & - & - \\
\hline \multicolumn{8}{|c|}{ Profile 2 - typical soil lessivés (eroded) } \\
\hline ABtp & $0-20$ & 8.2 & 7.7 & 5.14 & 0.39 & 0.032 & 12 \\
\hline $\mathrm{Bt}$ & $20-40$ & 8.0 & 7.1 & 0.40 & 0.16 & 0.019 & 14 \\
\hline $\mathrm{Ck}$ & $40-70$ & 8.7 & 7.9 & 12.3 & - & - & - \\
\hline \multicolumn{8}{|c|}{ Profile 3 - gleyed soil lessivés } \\
\hline $\mathrm{A}(\mathrm{Bt}) \mathrm{p}$ & $0-50$ & 8.4 & 7.6 & 6.49 & 0.71 & 0.078 & 9 \\
\hline $\mathrm{A}(\mathrm{Bt}) \mathrm{p} 2$ & $50-55$ & 8.4 & 7.6 & 0.81 & 0.37 & 0.040 & 9 \\
\hline 2Etg & $55-75 / 100$ & 8.5 & 7.7 & 0.40 & 0.13 & 0.017 & 8 \\
\hline 2Btg & $75 / 100-110$ & 8.3 & 7.3 & 0.36 & 0.15 & 0.025 & 6 \\
\hline $2 \mathrm{Cg}$ & $110-160$ & 8.2 & 7.1 & 0.28 & - & - & - \\
\hline \multicolumn{8}{|c|}{ Profile 4 - typical deluvial chernozemic soil } \\
\hline Adelp & $0-30$ & 6.0 & 5.0 & - & 0.71 & 0.080 & 9 \\
\hline Adel2 & $30-55$ & 6.7 & 5.5 & - & 0.31 & 0.045 & 7 \\
\hline Adel3 & $55-80$ & 7.1 & 6.0 & 0.17 & 0.18 & 0.027 & 7 \\
\hline $2 \mathrm{Cg}$ & $80-120$ & 6.8 & 5.2 & - & - & - & - \\
\hline $2 \mathrm{G}$ & $120-150$ & 5.5 & 4.2 & - & - & - & - \\
\hline \multicolumn{8}{|c|}{ Profile 5 - typical deluvial chernozemic soil } \\
\hline Adelp & $0-32$ & 7.0 & 6.2 & 0.16 & 1.24 & 0.126 & 10 \\
\hline $2 \mathrm{Ab}$ & $32-75$ & 7.3 & 6.3 & 0.20 & 1.25 & 0.086 & 15 \\
\hline $2 \mathrm{Gk}$ & $75-110$ & 8.5 & 7.5 & 9.18 & - & - & - \\
\hline
\end{tabular}

vidual components of the association on the map is only feasible following completion of detailed field mapping. The contours, in case of vast hills, are shaped like oval rings surrounding the pelosols and correspond to upper and middle parts of slopes. Within the surface of Zbiczno, the association adopts a form of small oval allocations located on slight in terms of the surface area convex formations.

Another association is produced by deluvial soils (shallow and deep ones) covering the gleyed soils [Adelp-2Cg$2 \mathrm{G}$ lub Adelp-Adel2-2Cg-2G] or soil lessivés, including soil lessivés non-covered with deluvia [Ap-Et-Bt-Ck]. The aerial photographs show that surface horizons of these soils have relatively uniform light grey colour, which impedes photointerpretative differentiation of individual soils. Deluvial soils rated among discussed allocations arose as a result of the accumulation of material from eroded humus and eluvial horizons of soil lessivés located on the slopes. This association creates a unique "soil background" and occupies definitely the greatest surface areas on both study areas.

Ranges of shallow deluvial soils $(30-50 \mathrm{~cm})$ prevailing in black earths and organic soils are easy to determine due to dark grey surface colour tones. Ranges of soils and gleyed soils and gleyed soils covered with deluvium of thickness up to $30 \mathrm{~cm}$ pose greater photointerpretative problems. The separation of these two units was possible 
1) Sumowo

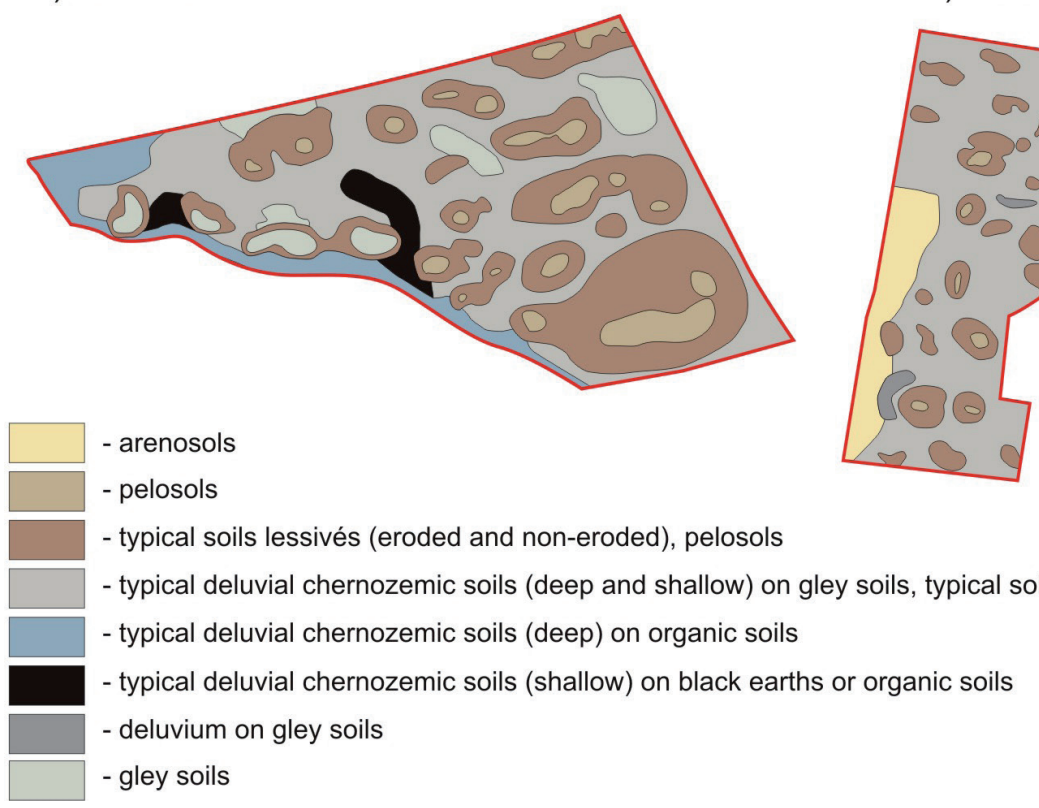

2) Zbiczno

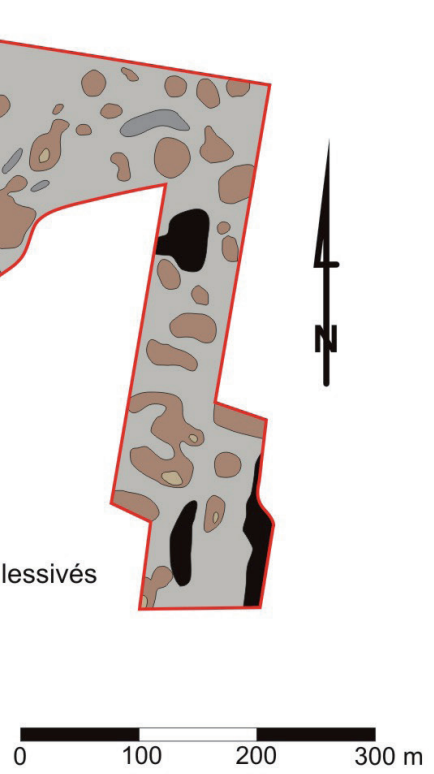

Figure 5. Soil maps of the Sumowo and Zbiczno site

only after field mapping completion. In both cases, the colour of surface horizons is grey.

The other two allocations are associated with soils developed in the edge zone between the moraine plateau and morphogenetic units of another type. The south-western boundary of Sumowo site is formed by deep deluvial soils covering the organic sediments developed within the biogenic plain. Whereas the arenosols located in the western part of the site Zbiczno are formed from deep, sandy sandur sediments. Originally these sands probably produced rusty soils, which as a result of anthropogenic denudation were truncated.

\section{Conclusions}

The anthropogenic denudation played a key role in shaping the present soil cover in plateau areas of Brodnica Landscape Park. The analysis of aerial photographs combined with carried our field survey and laboratory tests enabled development of photointerpretative key setting out the relationship between the taxonomic variability of soil units and the colours of surface horizons. This key can be a useful tool in further studies of extent and range of soil cover transformations related to anthropogenic denudation. Allocated based on the analysis, soil units feature varied degree of complexity - from homogeneous units containing a single soil type through associations containing various types of soils.
The photointerpretative analysis enables easy and accurate estimation of range of soils totally eroded produced from carbonate glacial tills. Calcium carbonate gives the surface horizons a very specific, light brown colour.

Brown colours cannot be interpreted merely as an evidence of occurrence of partially eroded soil lessivés. This is because this colour is specific for different types of soil: eroded soil lessivés of excavated argic horizons, soil lessivés covered with material of horizons Bt eroded at higher elevations, and pelosols made of carbonate-free glacial tills.

The largest areas are occupied by the soils of grey tones of surface horizons. The brightness of this colour is determined by both, high moisture and organic matter content. Dark grey colours are mostly specific for shallow deluvial soils (deluvia thickness up to $50 \mathrm{~cm}$ ) covering the excavable horizons rich in organic matter. A dark shade of discussed deluvium results from agricultural mix of deluvium and strongly humic or organic material from deeper (buried) horizons. Light grey colours feature in turn deep deluvial soils where the surface horizons are mainly derived from eroded soil lessivés and contain slight amounts of organic carbon. Hovever, the grey shade cannot be the only criterion for estimation of deluvium thickness. In the course of the study, considerable amounts of shallow deluvial soils, featuring light grey colours of surface horizons, were found. Low content of organic matter is in this case related to lack of located deeper, buried horizons, rich in humus. 
Most of deluvial soils of investigated area were formed as a result of accumulation of material from eroded soil lessivés. Hence, the surface horizons of soil lessivés feature properties resembling humus horizons of soil lessivés located in higher field elevations. Separation of those two units requires conformation of photointerpretative analysis results with detailed field investigations.

\section{Ancknowledgements}

Present studies belong to wider research project covering various types of anthropogenic transformations of Brodnica Lake District soils and were co-funded from MNiSW grant no. N N305 283337.

\section{References}

Alba S., Lindstrom M., Schumacher T. E. \& Malo D. D., 2004, Soil landscape evolution due to soil redistribution by tillage: a new conceptual model of soil catena evolution in agricultural landscapes, Catena 58: 77-100.

Baraniecki L., 1967, Badanie zmywów powierzchniowych w terenach słabo nachylonych przy pomocy zdjęć lotniczych [Using aerial photos in investigations of surface washings and denudation streaks in flat and weakly undulated areas], Fotointerpretacja w geografii 6: 39-43.

Bednarek R. \& Szrejder B., 2004, Struktura pokrywy glebowej zlewni reprezentatywnej Strugi Toruńskiej [Soil cover structure of the representative catchment of Struga Toruńska River], ZMŚP, Toruń: 243-252.

Bieniek B., 1997, Właściwości i rozwój gleb deluwialnych Pojezierza Mazurskiego [Properties and development of deluvial soils in Mazurian Lakeland] Acta Academiae Agriculturae Technicae Olstenensis. Agricultura, 64 supl. B, Olsztyn.

Gacki T. \& Gołębiewski R., 1977, Fotointerpretacja erozji gleb obszarów młodoglacjalnych na przykładzie zlewni górnej Raduni [Photointerpretation of soil erosion in the youthful glacial areas exemplified by the drainage basin of the upper Radunia River], Fotointerpretacja w geografii 10: 102-113.

Józefaciuk C. \& Józefaciuk A., 1996, Mechanizm i wskazówki metodyczne badania procesów erozji [The Erosion Mechanisms and Methodological Indicators for the Research on Erosion], Bibl. Monitor. Środow., Warszawa.

Kęsik A., 1969, Problemy erozji gleb i interpretacji zdjęć lotniczych na przykładzie północnej krawędzi Kotliny Chodelskiej koło Dobrego [Problems of soil erosion and air photos interpretation - on the example of northern ridge of Chodel Valley near Dobre], Fotointerpretacja w geografii 7: 47-66.
Koćmit A., 1998, Charakterystyka zmian w morfologii i właściwościach gleb uprawnych spowodowanych erozją wodną w obszarach młodoglacjalnych Pomorza [Characteristics of changes in morphology and properties of arable soils caused by water erosion on young glacial areas of Pomerania], Zeszyty Problemowe Postępów Nauk Rolniczych 460: 531-557.

Marcinek J. \& Spychalski M., 1987, Wpływ zawartości materii organicznej na fizyczne właściwości gleb hydromorficznych [The influence of organic matter content on physical properties of hydromorphic soils], Roczniki Akademii Rolniczej w Poznaniu 182: 19-33.

Marcinek J. \& Komisarek J., 2004, Antropogeniczne przekształcenia gleb Pojezierza Poznańskiego na skutek intensywnego użytkowania rolniczego [Anthropogenic transformation of the soil as a result of intensive agricultural use in Poznan Lakeland], AR, Poznań.

Munsell Soil Colour Charts, 2000, GreagMacbeth, New Windsor.

Niewiarowski W., 1973, Rzeźba terenu i budowa geologiczna Doliny Drwęcy i jej otoczenia (w granicach województwa bydgoskiego) i ich wpływ na zagrożenie erozją gleb [The relief and geological structure of Drwęca Valley and its surroundings (within the province of Bydgoszcz) and their impact on the risk of soil erosion], AUNC, Geography 9 (31): 44-45.

Niewiarowski W. \& Wysota W., 1986, Poziomy wysoczyznowe Wysoczyzny Brodnickiej [Moraine plateau levels of the Brodnica Moraine Plateau and their genesis], AUNC, Geography 19 (60): 39-46.

Orzechowski M., 2008, Właściwości gleb erodowanych i deluwialnych na Pojezierzu Mazurskim i Nizinie Sępopolskiej [The properties of eroded and deluvial soils in the Mazurian Lakeland and the Sępopolska Plain], Roczniki Gleboznawcze 59 (3/4): 236-242.

Orzechowski M., Smólczyński S. \& Sowiński P., 2001, Właściwości gleb obniżeń śródmorenowych Pojezierza Mazurskiego [The properties of soil within morainic depressions of the Mazurian Lakeland], Zeszyty Problemowe Postępów Nauk Rolniczych 476: 229-235.

Phillips J. D., Slattery M. \& Gares P. A., 1999, Truncation and accretion of soil profiles on coastal plaincroplands: implications for sediment redistribution, Geomorphology 28: 119-140.

Piaścik H., Sowiński P., Orzechowski M. \& Smólczyński S., 2001, Sekwencja gleb obniżeń śródmorenowych w krajobrazie młodoglacjalnym Pojezierza Mazurskiego, Zeszyty Problemowe Postępów Nauk Rolniczych 476: 491-496.

Piaścik H. \& Sowiński P., 2002, Wpływ denudacji antropogenicznej na rozwój gleb obniżeń śródmorenowych w krajobrazie Pojezierza Mazurskiego [The influence of anthropogenic denudation on the development of soil within morainic depressions of the Mazurian 
Lakeland], Zeszyty Problemowe Postępów Nauk Rolniczych 487: 249-258.

Polish Soil Classification, 2011, Soil Science Annual 62, 3.

Sinkiewicz M., 1977, Dawne i współczesne procesy denudacyjne w okolicy Witowic (Kujawy) w świetle analizy zdjęć lotniczych [Current and former processes of denudation in the area of Witowice (Kujawa) in light of the aerial photographs analysis], Fotointerpretacja w geografii 10: 82-99.

Sinkiewicz M., 1990, Interpretacja zdjęć lotniczych jako metoda badania przeobrażenia stoków uprawnych wskutek denudacji antropogenicznej na przykładzie wybranych obszarów Polski północnej [Interpretation of aerial photographs as a method to study the anthropogenic denudation on selected areas of the Northern Poland], Wyd. UMK, Toruń.

Sinkiewicz M., 1998, Rozwój denudacji antropogenicznej w środkowej części Polski północnej [The development of anthropogenic denudation in central part of Northern Poland], UMK, Toruń.

Stasik R. \& Szafrański C., 2005, Zmiany w pokrywie glebowej erodowanych terenów Pojezierza Gnieźnieńskiego [Soil cover changes of eroded areas in Gniezno Lakeland], Acta Agrophysica 5 (2): 447-454.

Szrejder B., 1998, Niektóre właściwości i pozycja systematyczna gleb powstałych w wyniku denudacji antropogenicznej w Koniczynce na Wysoczyźnie Chełmińskiej [Some properties and taxonomic position of soils evolved as a result of anthropogenic denudation in Koniczynka on the Chełmno morainic plateau], Zeszyty Problemowe Postępów Nauk Rolniczych 460: 499-511.
Szrejder B., 2000, Przestrzenna zmienność pokrywy glebowej dorzecza Strugi Toruńskiej i czynniki ją determinujące [Spatial variability of Struga Toruńska catchment soil cover and factors that determine it], Manuscript of $\mathrm{PhD}$ thesis, UMK, Torun.

Świtoniak M., 2010, Transformation of vertical texture-contrasted soils due to accelerated erosion in young glacial landscapes, North-Eastern Poland, 19th World Congress of Soil Science, Soil Solutions for a Changing World, 1 - 6 August 2010, Brisbane, Australia. Published on DVD.

Świtoniak M., 2011, Przekształcenia pokrywy glebowej obszarów wysoczyznowych Pojezierza Brodnickiego w wyniku oddziaływania denudacji antropogenicznej [Alternation of soil cover due to accelerated erosion in morainic plateaus of Brodnica Lake District], [in:] Wybrane problemy genezy, systematyki, użytkowania i ochrony gleb regionu kujawsko-pomorskiego, M. Jankowski [ed.], Wrocław, Warszawa, Polish Humic Substances Society, Polish Society of Soil Science: 227247.

Uggla H. \& Mirowski Z., 1960, Wpływ erozji wodnej na morfologię i niektóre właściwości chemiczne gleb na kilku wzgórzach morenowych Pojezierza Mazurskiego [The influence of water erosion on morphology and selected properties of soils developed on morainic hills in Mazurian Lakeland], Roczniki Nauk Rolniczych. Seria F t. 74 (2): 219-242.

Uggla H., Mirowski Z., Grabarczyk S., Nożyński A., Rytelewski J. \& Solarski H., 1968, Proces erozji wodnej w terenach pagórkowatych północno-wschodniej części Polski [Water erosion in undulating areas of NE Poland], Roczniki Gleboznawcze 18 (2): 415-446. 
